\title{
Revitalisering af PBL i videregående uddannelser ved brug af Learning Design
}

\section{Jacob Davidsen}

Adjunkt, p.hd.

Jacob Davidsen er adjunkt ved Institut for

Kommunikation på Aalborg Universitet. Han er

tilknyttet forskningscenteret e-Learning Lab - center for brugerdrevet innovation, læring og design. Jacob er særligt interesseret i samspillet mellem it og læring, samt hvordan læring og læreprocesser kan studeres og synliggøres gennem videobaserede multimodale interaktionsanalyser.

\section{Ulla Konnerup}

Adjunkt, P.hd.

Ulla Konnerup er adjunkt ved Institut for

Kommunikation på Aalborg Universitet. Hun er tilknyttet forskningscenteret e-Learning Lab - center for brugerdrevet innovation, læring og design. Ulla er særligt interesseret i virtuel læring og ikt-medieret specialpædagogik. 


\section{Abstract}

Gennem de sidste 10 år har større studenteroptag og begrænsede ressourcer på Aalborg Universitet (AAU) ledt til flere klassiske forelæsninger, hvilket har resulteret $i$ en udvanding og af de grundlæggende PBL principper. Vi argumenterer for, at en revitalisering af PBL gennem brugen af Learning Designs er en mulighed til at kvalificere den tilgang til læring og uddannelse, som i mere end 40 år har været kendetegn for AAU. Med afsæt i en case fra Kommunikation og Digitale Medier (KDM) afdækker vi, hvordan Learning Design kan fungere som et deskriptivt sprog og en form, der kan danne grundlag for udvikling og kvalificering af kurser, undervisnings- og læringsaktiviteter. Indenfor feltet Learning Design spores to retninger: 1) en retning med fokus effektivisering og standardisering af uddannelse og 2) en retning med fokus på udvikling, formgivning og kvalificering af uddannelse. I denne artikel diskuterer vi potentialer og udfordringer ved at konceptualisere PBL forløb som et Learning Design.

\section{Abstract}

Through the last 10 years, increasing numbers of students and a lack of resources at Aalborg University (AAU) have resulted in more classical lectures, which have occasioned a watering down and ritualization of the founding principles of PBL. In this paper, we argue that a revitalization of the PBL at AAU could be facilitated through the application of Learning Design. By using a case from Communication and Digital Media (CDM) we explore how Learning Design can act as a descriptive language and form, which can support the development of courses, teaching, and learning activities. Within the field of Learning Design two positions can be identified: 1) a position focusing on finding more effect and standard ways of running education, and 2) a position focusing on development and design of education. In this paper we discuss potentials and challenges of conceptualizing PBL as a Learning Design.

\section{Introduktion}

"More detailed and possible restrictive rules might structure a dance improvisation, rules that specify, for example, a certain kind of improvisation or certain sequences of movement: "contact improvisation only", for instance, or "fast group movement to alternate with slow, large individual movement". Such rules notwithstanding, the aim of the dancers is not to render something planned or choreographed in advance. Whatever the framing rules might be that act as a constraint upon movement, the aim of the dancers is to from movement spontaneously. It is to dance this evening's dance, whatever it might turn out to be."

Sheets-Johnstone, 2011, s. 420 
I musikken fungerer nodesystemet som et fælles sprog til at beskrive regler, former og sekvenser, hvilket man har ladet sig inspirere af indenfor det emergende felt Learning Design til at udvikle et fælles sprog og en fælles form (Dalziel, Conole, Wills, Walker, Bennett, Dobozy, Cameron, Badilescu-Buga, \& Bower, 2013). Selvom et fælles deskriptivt sprog og en fælles form kan virke appellerende i forhold til at dele og udvikle undervisning i og på tværs af undervisere, fag og institutioner, så rummer dette nogle vanskeligheder, som indfanges i ovenstående citat omkring improvisationsdans. Sheets-Johnstone (2011) argumenterer for, at annoteringer kan opsætte nogle retningslinjer for dansere, men at deres fortolkning og udtryk kan variere afhængigt af omgivelser, historie og udøver. Derfor noterer Sheets-Johnstone, at selv berømte danse skal betragtes som denne aftens dans - udtrykket og oplevelsen af dansen skifter fra aften til aften, fra sal til sal, fra kultur til kultur og fra danser til danser. Fælles for danseren og underviseren er, at de ikke ved, hvordan publikum reagerer på deres forberedte aktivitet, og at hver forestilling og undervisningsgang former sig i nuet og i et dynamisk samspil mellem de implicerede aktører. Men hvor danserne udvikler deres udtryk, form og udførelse gennem øvelse bag scenen individuelt og i fællesskab, træder underviseren direkte ind på scenen med de studerende som deltagere eller konsumenter. Og hvor danseren skal give publikum en oplevelse af en bestemt dans, så skal underviseren undervise de studerende og facilitere en erkendelse i forhold til et givent emne.

I denne artikel bygger vi videre på analogien om improvisationsdans i relation til feltet Learning Design. Vi diskuterer potentialer og udfordringer ved Learnings Designs, specifikt Learning Design Conceptual Map, og om det kan fungere som en annotering, et fælles sprog og en fælles form, der kvalificerer og effektiviserer uddannelse baseret på PBL. Vores grundantagelse er, at Learning Designs gennem ekspliciteringen af et fælles sprog og en fælles form kan være med til at sikre kvalitet i uddannelse ved at facilitere refleksion og diskussion mellem undervisere og vejledere på de videregående uddannelser. Ifølge Hüttel og Gnaur (2015) er der gennem de senere år sket en rutinisering og en udvanding af PBL på AAU bl.a. på grund af manglende dybdegående forståelse af, hvad det vil sige at holde et PBL universitet. Hüttel og Gnaur (2015) adresserer kvalitetsproblemer på AAU og ser vanskeligheder i forhold til udfolde studieordningen samt i forhold til at introducere de grundlæggende PBL principper for de studerende. Det er derfor nødvendigt at vitalisere PBL ved at sætte fornyet fokus på de bagvedliggende pædagogiske og filosofiske grundforståelser.

\section{PBL - en tilgang til uddannelse}

Internationalt og nationalt fremhæves problemløsning, samarbejde og kommunikation som kompetencer fremtidens arbejdsstyrke skal beherske (Voogt \& Roblin, 2012), men hvordan skal de studerende lære disse kompetencer og hvordan skal vi som undervisere på de videregående 
uddannelser forholde os til dette i undervisning og vejledning? Siden 1974 har AAU udviklet principper og modeller for PBL, og kandidater fra AAU er netop blevet uddannet til at løse problemer, indgå i samarbejdsrelationer og til at kommunikere med forskellige aktører på et globaliseret arbejdsmarked (Holgaard, Ryberg, Stegeager, Stentoft \& Thomassen, 2014). Holgaard et al. (2014) skelner mellem to sæt af kompetencer: de professionsspecifikke kompetencer, der relaterer sig til teoretisk og metodisk mestring af en profession og de PBL-relaterede kompetencer, der relaterer sig til at kunne analysere en problemstilling, kritisk anvende teorier og metoder og komme frem til en mulig forståelse og omorganisere sin måde at tænke og handle på. I denne sammenhæng har vi fokus på, hvordan det emergerende felt Learning Design kan bruges til at kvalificere arbejdet med de PBL-relaterede kompetencer på AAU. Selvom PBL anses som et særkende for AAU, så har stigende optag, udfordringer på de fysiske omgivelser, en periode, hvor gruppeeksamener var erstattet af individuelle eksamener (Dahl \& Kolmos, 2015), resulteret $i$, at en betydelig del af undervisningen foregår som forelæsninger i auditorier, og at vejlederne ikke nødvendigvis arbejder konstruktivt med PBL principperne i deres vejledning (Dahl \& Hüttel, 2016). Dertil kommer ifølge Hüttel og Gnaur (2015), at de standardiserede studieordninger formet af Bologna-forfatning har ensrettet og rutiniseret uddannelserne på AAU. For at håndtere disse problemstillinger er det vigtigt at udvikle en kultur og form blandt underviserne, der kan sikre kvaliteten af undervisningen og vejledningen, og her ser vi potentialer ved dele af Learning Design.

PBL er kort fortalt forankret i konstruktivistiske og sociale læringsteorier og trækker på teoretikere som Dewey (1916), Lave og Wenger (1991), Negt (1977), Piaget (2002), Vygotsky (1978). Der er variationer i de nævnte teoretikeres forståelse af læring (som vi ikke behandler i denne artikel, men se Andersen og Kjeldsen (2015) og Kolmos, Fink, og Krogh, (2004) for en grundig introduktion), men de fremhæver alle, at læring er en aktiv proces, der finder sted gennem sociale interaktioner, peer-to-peer-læring og tager udgangspunkt i virkelighedsnære problemstillinger. I forlængelse af disse læringsteoretiske og uddannelsesfilosofiske tilgange er PBL kendetegnet af idealer om gruppearbejde, samarbejde, problemorientering og studenterstyret organisering. Dertil kommer, at undervisere indenfor PBL indtræder som vejledere med fokus på produkt og proces i de studerendes projekt- og problemorienterede arbejde over en længere periode af semestret. Sluttelig eksamineres grupperne i deres projektenhed.

Kolmos (2002) argumenterer for, at det læringsteoretiske udgangspunkt for PBL er centralt, da PBL ikke kan reduceres til en pragmatisk tilgang til det at holde uddannelse. Igennem tiden har forskere og undervisere reflekteret over kendetegn ved AAU-PBL, eksempelvis arbejder Krogh (2002) med tre kendetegn for PBL; problemorientering, tværfaglighed og deltagerstyring dette er både forstået som filosofi og pragmatik. I takt med at PBL er blevet et 
brand for AAU, har AAU udviklet principper for det projekt og problemorienterede arbejde, som afspejles i undervisning, vejledning og projektarbejde. I den nuværende form udmønter AAU-PBL sig i følgende principper (Askehave, Linnemann Prehn, Pedersen, \& Thorsø Pedersen, n.d.):

-Problemet er omdrejningspunktet for den studerendes læreproces

-Projektorganisering skaber rammen for problembaseret læring

-Kurser understøtter projektarbejdet

-Samarbejde driver et problembaseret projektarbejde

-Gruppernes problembaserede projektarbejde skal være eksemplarisk

-De studerende har ansvar for egen læring

Gennem flere års deltagelse i planlægning, udfoldelse og evaluering af undervisning har vi erfaret, at selvom disse principper er fælles for den overordnede pædagogiske tilgang på tværs uddannelser på AAU, så varierer udfoldelsen af disse principper blandt undervisere og vejledere. Nogle undervisere og vejledere er opvokset med AAU-PBL, mens andre har erfaring med mere klassiske former uddannelse - herunder forelæsninger og pensumlister. Dertil kommer at planlægningen af kurser og undervisning ofte er et individuelt anliggende. Det kommer eksempelvis til udtryk i bemandingen af kurser, som ofte varierer fra år til år, men som også er baseret på administrative afmåling i forhold til timer og undervisningslokaler og $\mathrm{i}$ mindre grad i forhold til faglige og pædagogiske hensyn forankret i PBL principperne. I flere af de undervisningssammenhænge, vi selv er en del af, er koordinering og samstemmighed blandt underviserne reduceret til anliggender omkring mulige datoer og ikke det samlede kursusforløb. Det samme gør sig gældende i forhold til vejledergruppen på et semester, som kan have varierende tilgange til det projekt og problemorienterede arbejde. Selvom Savin-Baden (2000) karakteriserer PBL som en fleksibel og flerstemmig tilgang til uddannelse og læring, hvor problemet er centralt, så bør de centrale principper for AAU-PBL reflekteres i undervisning og vejledning på AAU. I det følgende introduceres Learning Design, hvorefter vi diskuterer om denne tilgang til det at designe uddannelse kan fællesgøre, udvikle og sikre kvalitet.

\section{Learning Design}

Begrebet Learning Design er blevet brugt i flere forskellige sammenhænge nogle benytter det til at beskrive en teknisk arkitektur til understøttelse og deling af Learning Designs, mens andre beskriver strukturerede sekvenser af information og aktiviteter til læring (Conole, 2009). I takt med udviklingen af web 2.0 er fokus ligeledes flyttet fra indhold til mere innovative, engagerende og producerende aktiviteter online. Den teknologisk udvikling spiller derfor en stor rolle i udviklingen af de forskellige positioner inden for Learning 
Design, hvilket vi vender tilbage til. I en dansk kontekst har Dohn og Hansen (2016) afdækket begrebet didaktisk design med afsæt i national og international forskning omkring feltet Learning Design og didaktik, hvilket giver forfatterne anledning til at bruge konceptet "betinget-kreativ formgivning" (s. 48). Denne måde at forholde sig til Learning Design på vender vi tilbage til, men i det følgende vil vi give en kort introduktion til nogle af retningerne indenfor feltet Learning Design.

Vi fastholder det engelske Learning Design med reference til definitionen fra Dalziel et al. (2013), hvor hovedformålet er at udvikle et fælles beskrivende sprog, kvalificere og dele undervisningsaktiviteter samt opbygge en bedre praksis for e-læring med fokus på samarbejde og aktiviteter. Begrebet skal dog forstås som en samlet betegnelse for 3 komponenter; 1) Learning Design Conceptual Map, der beskriver det samlede pædagogiske landskab, vedrørende centrale komponenter i et Learning Design 2) Learning Design Framework, der tilbyder et fælles sprog/notationssystem format / visualisering til at beskrive undervisnings- og læringsaktiviteter (kan være baseret på forskellige pædagogiske tilgange og 3) Learning Design Practice, der kan beskrives som konsekvensen af at anvende Learning Design koncepter samt gennemførelse af undervisnings- og læringsaktiviteter, også kaldet "designe for læring" (Dalziel et al., 2013).

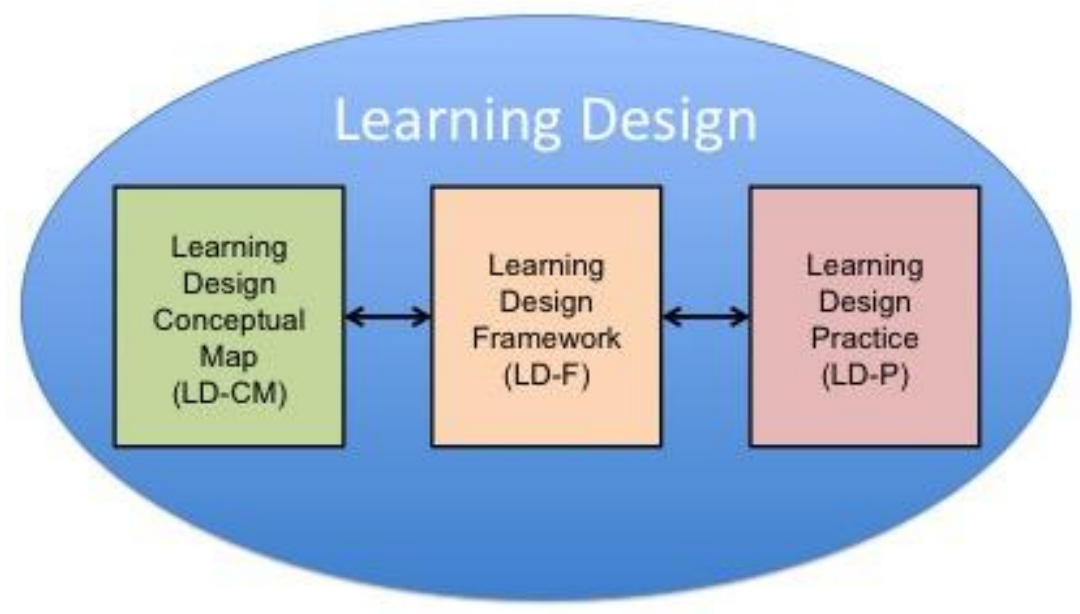

Figur 1 Learning Design's 3 komponenter (Larnaca Declaration 2013)

Figur 1 viser således en deskriptiv kortlægning af det pædagogiske landskab som det første af tre skridt i Learning Design. Hvad angår Learning Design Framework er vi enige i, at det på baggrund af den deskriptive kortlægning 
tilbyder fælles sprog og form, men uenige i at det kan ske uafhængigt af de bagvedliggende pædagogiske og filosofiske tilgange. Rammesætningen og sproget knytter sig til og formgives af den pædagogisk-filosofisk tilgang og sproget herom. På samme måde mener vi, at praksis altid vil udformes afhængigt af aktører og kontekst.

Begrebet Learning Design blev udviklet op gennem 00érne på baggrund af forskningssamarbejder, konferencer og projekter mellem uddannelsesforskere (Laurillard 2002; Conole 2013; Goodyear \& Retalis 2010; Dalziel 2003; Beetham \& Sharpe, 2007). Informationsteknologiens og særligt internettets indflydelse i samfundet gav anledning til refleksioner om, hvorledes disse nye muligheder kunne implementeres i uddannelse og læring på bedst mulig vis. Deklarationen udspringer endvidere af, at flere af forskerne frygtede, at informationsteknologien skulle resultere i ensidig behavioristisk og instruktivistisk vidensoverførsel til passive modtagere gennem software og standardiserede læseplaner. Eksempelvis argumenterer Laurillard (2008) for en konstruktivistisk model i følgende citat "not to transmit knowledge to a passive recipient, but to structure the learner's engagement with the knowledge, practising the high-level cognitive skills that enable them to make that knowledge their own" (2008, p. 527), og foreslår en repositionering af undervisningen til at være en designvidenskab, der anerkender lærernes rolle som designere for læring (2012). Dette ser vi som en pendant til Dohn og Hansens (2016) karakteristik af undervisere som formgivere af undervisning.

Hensigten bag Larnaca Declaration er, at Learning Design skal kunne operationaliseres på tværs af videnskabs- og læringsteoretisk udgangspunkter og tilgange med en høj grad af neutralitet, så de kan anvendes i forskellige sammenhænge. Selvom der spores en interesse i neutrale og universelle Learning Designs påpeger andre forskere, at opgaver og læringsaktiviteter transformeres og realiseres af undervisere og studerende i deres respektive omgivelser (Goodyear, Carvalho \& Dohn, in press). Carvalho og Goodyear (2014, s. 57) forholder sig kritisk til termen 'Learning Design' og påpeger, at den er misvisende. De foreslår, at forskere og undervisere i stedet bør anerkende at man kan designe opgaver og værktøjer, som kan støtte de lærende, men at man ikke kan designe læring.

Effektivisering af undervisning og læring står som sagt centralt i deklarationen (Dalziel et al., 2013). Til trods for det store fokus på effektivisering af uddannelse indenfor nogle grene af Learning Design, så nuanceres dette perspektiv gentagende gange, og i Larnaca Declaration skriver forfatterne, at det ultimative mål med Learning Design er at dele fremragende undervisningsideer med det sigte at forbedre de studerendes læring (Dalziel et al., 2013). Conole (2013) karakteriserer Learning Design som en metode, der skal muliggøre at undervisere træffer informerede valg i forhold til paletten af ressourcer og aktiviteter, de har til deres rådighed. 
Desuden understreger Conole processen omkring udviklingen af Learning Design
"A key principle is to help make the design process more explicit and shareable. Learning design as an area of research and development includes both gathering empirical evidence to understand the design process and the development of a range of learning design resources, tools and activities."

(Conole 2013, p. 8).

De forskellige positioner blandt forskerne understreger, at der ikke er en klar definition af Learning Design, og feltet er i gang med at etablere sig selv. I det følgende knytter vi didaktik og Learning Design sammen for at relatere det til vores egen uddannelseskontekst.

\section{Didaktik og Learning Design}

I skandinaviske sammenhænge har der ikke været tradition for at bruge begrebet design i forbindelse med læring og undervisning - Dohn og Hansen (2016) diskuterer således om begrebet 'didaktisk design' er et modeord eller en reel nyskabelse inden for undervisning. Læring er blevet set som en psykologisk proces og undervisning som underviserens praksis vedrørende den metodiske og systemiske tilrettelæggelse, gennemførelse og evaluering af undervisning, under ét som didaktik (Dohn og Hansen, 2016; Hiim \& Hippe, 1993; Illeris, 2006). Den bagvedliggende videnskabs- og læringsforståelse bør afspejles i undervisningspraksis. Således kan et naturvidenskabeligt videnskabssyn, som positivismen udmønte sig i en instruktivistisk mål-middel undervisning, der er trinvis, observerbar, curriculum-baseret og kontrollerbar, hvorimod et åndsvidenskabelig humanistisk orienteret syn ser undervisning og læring som en dannelsesproces, der vægter mening, relevans og sammenhæng mellem teori og praksis (Dalsgaard, 2004; Illeris, 2006).

Omend begrebet design ikke har været brugt tidligere i en skandinavisk kontekst, så har undervisere udviklet undervisnings og læringsmaterialer med afsæt i viden om modtager og fag (Westbury, 1998), hvilket har ligheder med Laurillards (2012) forslag til en repositionering af underviseren som designer. Dette perspektiv relaterer til forskellene mellem didaktik og curriculum, som vi finder relevant i forhold til anvendelsen af Learning Design i en dansk PBL kontekst, særligt i forhold til diskussionen om mulighederne for effektivisering af uddannelse. Westbury skitserer forskellene mellem didaktik og curriculum traditionen:

\footnotetext{
"Didaktik seeks to assist teachers in the complex deliberation by offering frameworks and models to crystallize "appropriate" patterns of thinking. Whereas the core task of curriculum centers on thinking about building and managing a controlling institutional (curricular) delivery system, Didaktik seeks to
} 
explicate, and then turn into a usable framework, deliberation about the educational (in the largest sense) problems which teacher reflection must and might engage."

(Westbury, 1998, s. 65)

I diskussionen tager vi forholdet mellem Learning Design og didaktik op igen, men inden vi præsenterer casen vil vi fremhæve et sidste perspektiv for at belyse Learning Design - Dalziel (2013, s. 13) forstår Learning Design som en form for meta-abstraktionslag over eller ved siden af pædagogiske traditioner og tilgange til undervisning og læring.

\section{"Learning Design is not a traditional pedagogical theory like, say, constructivism. Learning Design can be viewed as a layer of abstraction above traditional pedagogical theories in that it is trying to develop a general descriptive framework that could describe many different types of teaching and learning activities."}

Dalziel (2013, s. 13)

Spørgsmålet er, om man overhovedet kan se sig fri fra pædagogik og læringsteori i beskrivelsen og deling af Learning Designs, som foreslået af Dalziel (2013, s. 13). Selv et generelt deskriptivt framework baseret på et neutralt sprog vil indeholde ideologiske elementer fra bestemte undervisningsfilosofier og praksisser. Det er som Wittgenstein beskrev i følgende aforisme "Words are the chains that set us free" (citeret i Derry et al., 2007). Ord giver os mulighed for at kommunikere og skabe mening sammen, men vi er samtidig begrænsede af ordene, vi har til rådighed mellem deltagerne i situationen. I relation til Learning Design giver et fælles neutralt sprog muligheder for at sprede og dele innovative undervisningsforløb, men ordene er ikke neutrale - de kan fungere som lænker i forhold til at det didaktiske arbejde underviseren og vejlederen står overfor. Det er derfor vigtigt at være bevidst om sproget i arbejdet med at udvikle Learning Designs.

Med denne korte introduktion til nogle af de forskellige positioner indenfor feltet Learning Design, samt relationerne til en skandinavisk didaktisk position, bevæger vi os videre til præsentationen af casen. Med casen ønsker vi at illustrere og diskutere potentialer og udfordringer ved at beskrive et PBL-forløb i et Learning Design Conceptual Map.

\section{Case - Learning Design i en PBL kontekst}

Vi præsenterer en konkret case fra KDM ved AAU og sætter pædagogiske overvejelser og aktiviteter ind i et Learning Design Conceptual Map. Herefter vil vi diskutere Learning Designs hovedformål, og hvorvidt begrebet er anvendeligt til at kvalificere videregående uddannelser, hvor den overordnede 
pædagogiske tilgang er PBL. Endelig vil vi diskutere, om en konceptualisering af et konkret modul på uddannelsen i et Learning Design Conceptual Map kan resultere i et fælles sprog og en fælles form, som kan formidle modulets ideer og forløb til kolleger og ledelse på universitetet.

Casen omhandler et modul på 5. Semester på uddannelsen KDM på Det Humanistiske Fakultet. Det overordnede tema er "Kommunikationsdesign: læring, netværk og organisation". Semestret har 169 studerende, som er organiseret i to grupper, der arbejder med to forskellige cases. "Gruppe 1", den aktuelle case, består af 85 studerende. Gruppen skal planlægge, designe, gennemføre og evaluere et kursus om studierelevante informations og kommunikationsteknologier til de nye studerende på 1. semester, med fokus på læring, koordinering, projektstyring, kollaborative skriveprocesser og samarbejde. Studerende på 5. semester skal designe et to dags kursus, som er obligatorisk for 1 . semester at deltage $\mathrm{i}$, da det er en del af introduktionen til PBL (5 ECTS i alt) på KDM.

Baseret på egne erfaringer og forskning ved vi, at de nye studerende ikke nødvendigvis er bekendte med studierelevante teknologier (Henderson, Selwyn \& Aston, 2015), men at de i høj grad anvender de sociale medier de bruger i deres privatliv. De studerende har kendskab til mange af teknologierne, men de har nødvendigvis ikke kompetencerne til at anvende dem i forbindelse med deres studie (Thomsen, Sørensen, \& Ryberg, 2016). Igennem snart 20 år har underviserne ved uddannelsen eksperimenteret med at lade studerende på 5 . semester undervise 1 . semester, da de ældre studerende gennem to år har erfaret betydningen af studierelevante teknologier i deres projekt og problemorienterede arbejde. Det er således 5. semesters opgave at formulere relevante problemstillinger med udgangspunkt i denne case baseret på egne erfaringer og tage ansvar for en "betinget-kreativ formgivning" (Dohn \& Hansen, 2016, s.48) af undervisningen af 1 . semester. Problemstillingen er nemlig betinget, da nogle af præmisserne for undervisningen er defineret af underviserne, men i særlig høj grad af PBL principperne (Konnerup \& Dirckinck-Holmfeld, 2016). Konnerup og DirckinckHolmfeld (2016) forklarer, at i takt med stigende optag, mangel på gruppe- og seminarrum, skiftende undervisere og studieledere, samt nye studieordninger, har modulet ændret karakter gennem årene, hvilket har resulteret i, at nogle af de læringsteoretiske og pædagogiske grundsten i kurset er blevet udvandet.

Den overordnede pædagogiske ramme er Fremtidsværkstedet, med dertilhørende regler og faser (Jungk \& Müller, 1984). Inden Fremtidsværkstedet havde underviserne fra 1. semester defineret nogle læringsmål for de nye studerende, som 5 . semester skulle forholde sig til i deres formgivning af kurset og undervisningsaktiviteterne. Samarbejdet og koordineringen mellem undervisere på 5 . semester og de studerende finder løbende sted gennem obligatoriske milepæle, hvor de studerende forholder sig til emner defineret af underviserne og præsenterer deres forslag til 
undervisning for 1. semester. Under milepælene skal de studerende endvidere give hinanden kritik, og komme med konstruktive forslag til gruppernes arbejde. Desuden er grupperne blevet bedt om at udarbejde en læringskontrakt med hinanden for at beskrive individuelle og kollektive forventninger til læringsudbyttet ved modulet. Alle læringsaktiviteter og ressourcer er blevet orkestreret gennem Moodle, et open source learning management system (LMS).

I følgende tabel opsummeres kurset i et Learning Design Conceptual Map, der bygger på studieordninger, underviser erfaringer og evalueringer af kurset:

\footnotetext{
Challenge

PBL tilgang og principper ved Aalborg udfordres i forhold til:

- Fysiske rammer: Vanskeligt at praktisere en studentercentreret og deltagerstyret tilgang baseret på en konstruktivistisk læringstilgang i auditorier med 200 studerende

- En årrække, hvor gruppeeksamen ikke var tilladt har haft indflydelse på de studerendes opfattelse og praksis omkring PBL

- 40 år med PBL strategien ført til ritualisering og udvanding af principperne, hvor undervisere kender til principperne uden at reflektere over den bagvedliggende filosofi og læringsteori

- Studerende har ikke en kultur for at deltage $\mathrm{i}$ dialog $\mathrm{i}$ auditoriet da akustikken ikke er velegnet til dialogbaseret undervisning og de føler sig utrygge
}

\begin{tabular}{|c|c|c|}
\hline $\begin{array}{l}\text { Educational } \\
\text { Philosophy }\end{array}$ & Teaching Cycle & $\begin{array}{c}\text { Level of } \\
\text { Granularity }\end{array}$ \\
\hline \begin{tabular}{|l|} 
Problem \\
Based \\
Learning \\
\end{tabular} & & Studieordning \\
\hline $\begin{array}{l}\text { Theories \& } \\
\text { Methodologies }\end{array}$ & $\begin{array}{cc}\text { Milepale } & \begin{array}{c}\text { Didaktiske } \\
\text { overvejelser }\end{array}\end{array}$ & $\begin{array}{l}\text { Semester } \\
\text { Modul }\end{array}$ \\
\hline $\begin{array}{l}\text { Socialkonstruk } \\
\text { tiv-tistisk } \\
\text { læringsteori }\end{array}$ & & $\begin{array}{c}\text { Undervisningsgan } \\
\text { ge }\end{array}$ \\
\hline \begin{tabular}{|l} 
Fremtidsværks \\
ted som \\
didaktisk \\
ramme \\
\end{tabular} & $\begin{array}{l}\text { med } \\
\text { studerende }\end{array}$ & Aktiviteter \\
\hline $\begin{array}{c}\text { Learning } \\
\text { Environment: }\end{array}$ & & \\
\hline $\begin{array}{l}\text { Characteristics } \\
\text { \& Values }\end{array}$ & $\begin{array}{l}\text { Evaluering } \rightarrow \text { Studienævn } \\
\rightarrow \text { videreudvikling og kvalitetssikring }\end{array}$ & \\
\hline
\end{tabular}




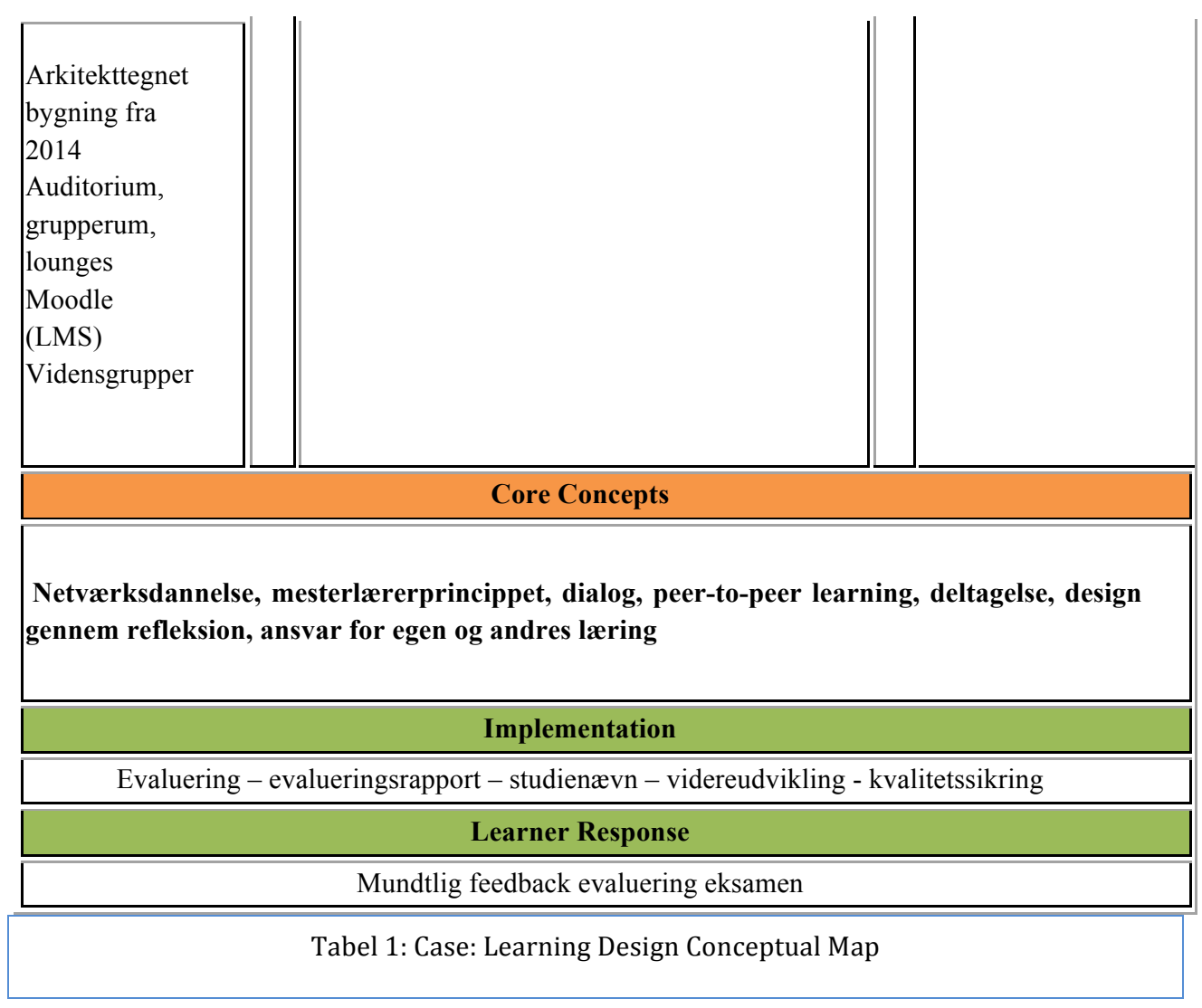

\section{Challenge}

Gennem en årrække er PBL tilgangen og principperne ved AAU blevet udvandet og rutiniseret på grund af større årgange på KDM, udfordringer i forhold til de fysiske rammer, samt en årrække, hvor gruppeeksamen ikke var tilladt på universiteterne i Danmark (Dahl og Hüttel, 2015). Endvidere har 40 år med PBL strategien ført til ritualisering af principperne (Hüttel \& Gnaur, 2015), hvor undervisere kender til principperne uden at reflektere over den bagvedliggende filosofi og læringsteori i deres tilrettelæggelse, udførelse og evaluering af undervisning og vejledning. Vores erfaringer er, at der blandt underviserne opleves store udfordringer $i$ at praktisere en studentercentreret og deltagerstyret tilgang baseret på en konstruktivistisk læringstilgang i auditorier med 180 studerende. Det viser sig ydermere (baseret på evalueringerne fra modulet), at de studerende ikke er vant til eller har lyst til at deltage i dialog $\mathrm{i}$ auditoriet, akustikken er ikke velegnet til dialog, de studerende føler sig utrygge ved at tale foran medstuderende og dialog er ikke blevet en del af deres kultur for deltagelse i forelæsninger.

Samtidig kan det høje antal studerende (i den aktuelle case 169) være en udfordring. For at spare tid og arbejde pædagogisk med samhørigheden mellem de studerende er alle studerende i underviserbestemte (efter et tilfældighedsprincip) 5-mandsprojektgrupper, hvilket er i modsætning til andre semestre, hvor de studerende selv danner grupper. Flere studerende tilkendegav, at de kom i gruppe med medstuderende, som de ikke kendte fra 
studiet gennem to år. Dette understreger den manglende samhørighed blandt de studerende på et semester, som kan påvirke kulturen for dialog.

\section{Educational Philosophy}

Den bagvedliggende og overordnede tilgang er AAU-PBL. Særligt for AAU-PBL er den projekt og problembaserede pædagogik, og at de studerende selv definerer problemstillinger, som for dem er virkelighedsnære, og som vil motivere deres arbejde.

\section{Theories \& Methodologies}

Læringsteoretisk er modulet funderet i socialkonstruktivismen. Studenterorientering og aktivitet er centralt, ligesom arbejdet med udarbejdelse af kursus for 1 . semester og efterfølgende rapport foregår i grupper. Rapporterne og de studerendes designprodukter fremlægges og diskuteres afsluttende med gruppeeksamen.

Et andet vigtigt element i tilgangen på dette kursus er fremtidsværkstedet, som beskrevet af Jungk and Müllert (1984). Fremtidsværkstedet er med til at forme den didaktiske ramme, hvor der indledes et 2 dages kick-off seminar efterfulgt af et permanent værksted med vidensindsamling, milepæle, forelæsninger og planlægning.

\section{Teaching Cycle}

Underviserne er ansvarlige for didaktikken og tilrettelægger undervisningen under hensyntagen til rammefaktorer (studieordning, lokaler og værktøjer) og de studerendes forudsætninger og formodede forforståelser af emnet.

Underviserene justerer undervejs form og indhold på baggrund af samvær og feedback fra de studerende under forelæsninger, break-out-sessioner (breakouts er en række korte workshops, hvor teknologier, metoder og ny viden præsenteres og diskuteres i et åbent forum mellem studerende og undervisere) og milepæle.

De studerende udfylder anonymt en elektronisk evaluering, som underviser kondenserer og sender til studienævnet. Den kondenserede rapport skal danne grundlag for videreudvikling og kvalitetssikring af næste års forløb.

\section{Learning Environment: Characteristics and Values}

PBL er en pædagogisk tilgang og strategi for alle uddannelser på AAU, men rammefaktorerne varierer mellem hovedområderne og de forskellige uddannelser. På KDM er underviserne organiseret i vidensgrupper, som skal fordele undervisning og vejledning i mellem sig. Lokaliteten for undervisningsaktiviteterne finder sted i en arkitekttegnet bygning fra 2014, men er udfordret på grund af manglende undervisningslokaler for undervisere og studerende på KDM. Forelæsninger og nogle kursusgange finder sted i auditorium med plads til 250 studerende med nyt audio/projektor-system til forelæser. Udover det fysiske læringsmiljø 
anvendes AAU's fælles Learning Management System (LMS) Moodle. Her orkestreres modulet med information fra undervisere og sekretærer til studerende om mål, aktiviteter, skema og nyheder. Generelt anvendes Moodle i vid udstrækning som materialebank og ikke som kommunikations- eller samarbejdsværktøj mellem undervisere og studerende (Bygholm \& Nyvang, 2013). Endvidere anvendes mange af de interaktive og dialogprægede funktioner (quizzes, databaser, afleveringer, mødeplanlægning, etc.) i Moodle i begrænset omfang af underviserne - og sjældent $i$ en systematisk tilgang af hele undervisergruppen på et semester. I dette modul sætter underviserne fokus på om Moodle har potentiale til at støtte studerendes projektarbejde og problembaserede læring - samt deltagelse i forelæsninger og workshops. Således er de studerende ansvarlige for at organisere møder med vejleder gennem Moodles booking system, oplæg og kritik fra milepæle uploades ugentligt, studerende gives administratorrettigheder på udvalgte kurser, så de selv kan være ansvarlige for opbygningen og strukturen. Det er således tale om et hybridt læringsmiljø, som mixer face-to-face undervisningen med online aktiviteter.

\section{Level of Granularity}

Modulets undervisning tager udgangspunkt i en studieordning fra 2010. Underviserne tolker den og detailplanlægger på baggrund af mål, tilknyttede undervisere, antal studerende og rammevilkår. Aktiviteterne og valg af litteratur besluttes delvist af modulansvarlig og delvist af de enkelte undervisere. I 2015 er der tilknyttet 8 undervisere til alle 169 studerende, hvoraf de 5 er involveret $\mathrm{i}$ undervisningen og resten i forbindelse med vejledningen. Udover traditionelle forelæsninger og fremtidsværkstedet, introduceres en række breakouts i et åbent lounge-område. Der er lagt op til, at 1-2 fra hver gruppe skal deltage og derefter formidle videre til resten af gruppen, hvilket er en ukendt organiseringsform for de studerende.

\section{Core Concepts}

Netværk, læring og organisering er centrale koncepter for vores Learning Design. Disse koncepter introduceres fra forskellige perspektiver gennem kursets forskellige aktiviteter. Dertil kommer fokus på relationen mellem disse koncepter og kursets indhold: studierelevante teknologier. Modulet kendetegnes yderligere af en række kernebegreber: netværksdannelse, mesterlærerprincippet, dialog, peer-to-peer learning, deltagelse, design gennem refleksion, ansvar for egen og andres læring

\section{Implementering}

Ved at evaluere og beskrive forløbet re-designes modulet med henblik på at gentage og udvikle modulet i efteråret 2016. 


\section{Learner Response}

De studerende er gode til i det daglige at give spontan respons gennem dialog og uformelle samtaler samt i vejledningen. Herudover er de til formel eksamen og de evaluerer skriftligt og anonymt. Dog kun med en svarprocent på $53 \%$ i den afsluttende evaluering.

Ovenstående uddybning af de forskellige punkter i Learning Design Conceptual Map indikerer kompleksiteten og forskelligheden af designet, men anvendelsen af et fælles sprog og en fælles form giver med stor sandsynlighed underviserne nogle værktøjer til at sikre kvaliteten af kurset $\mathrm{i}$ henhold til PBL principperne og tilgangen. Samtidig leder det frem mod et Learning Design Framework, der former sig på baggrund af den pædagogiske-filosofiske tilgang. Det 3. trin Learning Design Practice ligger mere åben afhængig af aktører og kontekst.

\section{Diskussion}

Vi ser muligheder for professionel og organisatorisk samarbejde og udvikling gennem brugen af Learning Design, specielt gennem kortlægning af konkrete forløb i et Conceptual Map, da det gennem skriftlig explicitering giver anledning til gensidig refleksion og forhandling aktørerne i mellem. Vi ser samtidig nogle spændinger, som kræver opmærksomhed fra institutionen, underviserne og vejlederne. Der er et behov for, at undervisere og vejledere på AAU samarbejder om at revitalisere PBL gennem dialog og samskabelse af undervisnings- og vejledningsaktiviteter for på denne måde at sikre et fælles sprog og en fælles form, som igen kan danne et Learning Design Framework. PBL principperne kan med andre ord være med til at betinge den kreative didaktiske planlægning, udførelse og evaluering. I det følgende diskuterer vi spændinger omkring Learning Design i relation til AAU-PBL, forholdet mellem Learning Design og didaktik og forholdet mellem kvalitet og effektivisering.

Udgangspunktet for Larnaca Declaration 2013 var en erkendelse af, at mulighederne for samarbejde omkring uddannelsesudvikling ændrede sig i takt med inddragelse af teknologi. Specielt brugen af internet og Web 2.0 inviterede til nye samarbejdsformer og kritisk tænkning omkring det at holde uddannelse (Anderson, 2005). For at kvalificere vores forståelse af det 21. århundredes kompetencer, er, vi som undervisere og forskere nødt til at samarbejde og udveksle erfaringer i forhold til at reformere undervisning, vejledning og studieordninger på tværs af institutioner, nationalt og internationalt. Her kan kortlægningen foreslået som et Learning Design Conceptual Map informere diskussionen og det forestående arbejde med udviklingen af uddannelser. Det er dog vigtigt, at det Learning Design Framework, der opstår på baggrund af kortlægningen fungerer som retningslinjer, inspiration og værktøjer for dialog og ikke som endegyldige svar og færdige modeller for underviserne. 
Baseret på vores erfaringer ser vi en fare i at "installere" Learning Design Conceptual Map og Framework fra en kontekst til en anden, da kultur, tradition og historie i en sociokulturel forståelse af læring spiller ind på praksis og betinger planlægningen, udfoldelsen og evalueringen af undervisningen og vejledningen. Learning Design Conceptual Map vil altid (lige som dansen) skulle tilpasses, den konkrete kultur, den konkrete situation og de konkrete aktører. Vi er enige $i$, at konceptualisering og eksplicitering af bagvedliggende anskuelser og ideologier for ens praksis kan medvirke til at skabe fælle forståelse, men risikoen for at denne formalisering og konceptualisering vil føre til ritualisering er til stede (se Hüttel og Gnaur (2015) for en diskussion af Bologna traktatens indflydelse på ensretningen af studieordninger). I Larnaca Deklarationen lægges der vægt på, at Learning Design skal være et deskriptivt sprog, således at det er op til praktikeren at tolke, forme og tilpasse kontekst og situation. Vi ser dog en fare for Learning Design kan blive forstået normativt, hvilket kan føre til reaktive måder at holde uddannelse på.

En anden spænding er forholdet mellem didaktik og Learning Design. Vi vil gerne problematisere termen Learning Design og især den direkte danske oversættelse, Læringsdesign. Vi finder det ikke retvisende for den betydning Larnaca deklarationens forfattere ønsker at fremhæve, nemlig "a descriptive framework for teaching and learning activities" eller "an educational notation" (Dalziel et al., 2013). Beskrivelserne knytter sig mere til undervisningen og grundlaget herfor og dermed didaktikken. I en dansk kontekst kan det give en spænding i forhold til forståelsen og dermed de divergerende forståelser, der kan være af begrebet. Man kan ikke designe læring, men man kan designe for læring (Wenger, 2004, s. 259). Som underviser og vejleder er du ansvarlig for det didaktiske, altså tilrettelæggelse, gennemførelse og evaluering af undervisning og læringsaktiviteter. Det er med Dohn og Hansens (2016, s. 61) ord "... af afgørende betydning, at man som didaktisk designer forstår kompleksiteten i didaktisk design - som domæne, som proces, som ide og som praksis" for at kvalificere og understøtte de studerendes læring.

Dette fører os videre til slutteligt at diskutere forholdet mellem effektivisering og/eller kvalitet med udgangspunkt i Learning Design. I litteraturen omkring Learning Design spores en stærk interesse i effektivisering af undervisning og læring gennem anvendelsen af allerede eksisterende Learning Designs. Denne tankegang minder om Westburys (1998) karakteristik af curriculum traditionens fokus på systemstyret og standardiseret undervisningsmateriale, hvor underviser er en udøvende agent for det centrale system. Man kunne forestille, sig at en underviser henter et Learning Design om algebra ned og ukritisk videregiver det til de studerende. Hvad opnår man med dette kvalitet eller effektivisering? Kvalitet og effektivisering hænger sammen i forhold til implementeringen og anvendelsen af Learning Design - men fra vores perspektiv kan relevansen af Learning Design gøres op i om der skabes forandringer i undervisnings og vejledningsaktiviteter baseret på refleksioner mellem underviserne. Ved at sætte en konkret case ind i Learning Design 
Conceptual Map bliver det tydeligt, at vi som undervisere ofte kun forholder sig til Teaching Cycle og Levels of Granularity (Tabel 1).De andre punkter tages til tider for givet, som fælles tavs viden, men diskussioner om aktiviteter og metoder kan vise at være divergerende syn og forståelser af uddannelsesfilosofi, metodologi og grundlæggende PBL principper. Et Learning Design kan give et fælles sprog, men det kan stadig rumme uklarheder grundet konteksten, historien, pragmatikken og menneskene omkring et Learning Design. Et Learning Design kan bruges til at gøre eksplicitere den didaktiske forståelse og handlerum gennem kortlægning og rammesætningen, men det er kritisk at forholde sig til, hvordan en underviser kan operationalisere et Learning Design i egen praksis. Vores vurdering er dog, at Learning Design kan være med til at højne og sikre kvalitet i uddannelse ved at facilitere refleksion og diskussion mellem undervisere og vejledere.

\section{Konklusion}

En klassisk scene i filmen The Matrix fra 1999 omhandler kompetenceudvikling hos filmens hovedperson - Neo - som skal lære om kampsport. Neo bliver placeret i en futuristisk stol og bliver koblet op til en avanceret computer - så installeres diverse kampsporter i Neos hjerne og krop - han ender med at sige "I know kong fu". Dette er den ultimative drøm om, at mennesket kan lære alt ved en simpel installationsproces, og at alle mennesker kan lære at udfører alt. Gør Learning Design undervisere og vejledere i stand til at undervise i alle tænkelige emner? - næppe.

Undervisning og vejledning er, som Sheets-Johnstones karakteristik af improvisationsdans, betinget af konteksten, omgivelserne, fag, ideologier, pædagogik, menneskene osv.. Learning Design kan være med til at kvalificere denne undervisningsgang ved at rammesætte og skabe opmærksomhed på de grundlæggende PBL principper mellem underviserne og vejlederne, så den pædagogiske tilgang revitaliseres på AAU. Learning Design Conceptual Map er en kortlægning med begreber, der er essentielle at forholde sig til under planlægning, udførelse og evaluering af undervisnings- og vejledningssituationer. De generiske punkter Learning Design Conceptual Map skal forstås som værende neutrale og nogle man kan forholde sig til på tværs uddannelsesfilosofi og læringsteoretiske positioner. Ved kontinuerligt at reflektere over de forskellige delelementer og deres relation til hinanden i Learning Design Conceptual Map, styrkes sammenhæng mellem pædagogisk/filosofisk strategi, læringsteori og didaktisk metode. Hvis ikke den bagvedliggende filosofi og læringsteori vedvarende reflekteres i didaktikken, risikerer vi en fortsat udvanding af PBL principperne og en ritualisering i praksis mellem underviser og vejledere. Learning Design skal således ses som mulighed for at udvikle deskriptive retningslinjer og som ikke bud på færdige trinvise standardiserede modeller. Gibbs (2013) foreslår at fokusere på kollektivet af undervisere, hvis kvaliteten af uddannelsen skal sikre og styrkes. Vi ser muligheder for, at bruge Learning Design som metode 
til at udvikle og styrke professionel og institutionel kompetenceudvikling, således at PBL revitaliseres i undervisning og vejledning på de videregående uddannelser.

\section{Referencer}

Andersen, A. S. \& Kjeldsen, T. H. (2015). Theoretical Foundations of PPL at Roskilde University. I: A. S. Andersen \& S. B. Heilesen (red.) The Roskilde Model: Problem-Oriented Learning and Project Work, s. 3-16. Springer.

Anderson, T. (2005). Distance learning-Social software's killer ap? Retrieved from http://auspace.athabascau.ca:8080/handle/2149/2328

Askehave, I., Linnemann Prehn, H., Pedersen, J., \& Thorsø Pedersen, M. (red.). (n.d.). PBL - Problem Baseret Læring. Aalborg universitet Rektorsekretariatet. Retrieved from http://www.aau.dk/digitalAssets/148/148026_pbl-aalborgmodellen_dk.pdf

Beetham, H. (2007). Rethinking pedagogy for a digital age : designing and delivering e-learning. London; New York: Routledge

Bitch Olsen, P., \& Pedersen, K. (2003). Problemorienteret projektarbejde. Roskilde Universitetsforlag.

Bygholm, A., \& Nyvang, T. (2013). IKT-støttet læring og kvalitet - erfaringer fra uddannelserne i Humanistisk Informatik på Aalborg Universitet. I Y. Nordkvelle, T. Fossland, \& G. Netteland (red.), Kvalitet i fleksibel høyere utdanning - nordiske perspektiver. Akademika Forlag.

Carvalho, L. \& Goodyear, P. (red). (2014). The architecture of productive learning networks. New York: Routledge.

Conole, G. (2007). Describing learning activities -Tools and resources to guide practice. I H. Beetham \& Rhona Sharpe (red.), Rethinking Pedagogy for a Digital Age: Designing and Delivering E-learning (s. 8192).

Conole, G. (2013). Designing for learning in an open world. New York ; Heidelberg: Springer.

Dahl, B., \& Hüttel, H. (2015). Studerendes oplevelse af reorganisering af problem-baseret læring på Aalborg Universitet. Dansk Universitetspaedagogisk Tidsskrift, 10(19), 43-55.

Dahl, B., \& Kolmos, A. (2015). Students' attitudes towards group based project exams in two engineering programmes. Journal of Problem Based Learning in Higher Education, 3(2). http://doi.org/10.5278/ojs.jpblhe.v0i0.1108

Dalsgaard, C. (2004). Pædagogisk vurdering af e-læringssystemer. I M. Georgsen \& J. Bennedsen (red.), Fleksibel Læring og Undervisning erfaringer, konsekvenser og muligheder med IKT (pp. 239-258). Aalborg: Aalborg Universitetsforlag. 
Dalziel, J. (2003). Implementing learning design: The learning activity management system (LAMS).

Dalziel, J., Conole, G., Wills, S., Walker, S., Bennett, S. Dobozy, E., Cameron, L., Badilescu-Buga, E. \& Bower, M. (2013). The Larnaca Declaration on Learning Design - 2013. Hentet på www.larnacadeclaration.org

Dewey, J. (1916). How we think.

Derry, S., Pea, R., Barron, B., Engle, R., Erickson, F., Goldman, R., ... Sherin, B. (2010). Conducting Video Research in the Learning Sciences: Guidance on Selection, Analysis, Technology, and Ethics. Journal of the Learning Sciences, 19(1), (s. 3-53.) http://doi.org/10.1080/10508400903452884

Dohn, N. B., \& Hansen, J. J. (2016). Begrebet “didaktisk design” - Et kritisk overblik over betydninger. In N. B. Dohn \& J. J. Hansen (red.), Didaktik, design og digitalisering (s. 43-64).

Gibbs, G. (2013). Reflections on the changing nature of educational development. International Journal for Academic Development, 18(1), (s. 4-14.)

Goodyear, P., Carvalho, L., \& Bonderup Dohn, N. (in press). Artefacts and activities in the analysis of learning networks. I V. Hodgson, M. de Laat, D. McConnell, \& T. Ryberg (Eds.), Research, Boundaries and Policy in Networked Learning. Cham: Springer International Publishing.

Goodyear, P., \& Retalis, S. (2010). Technology-enhanced learning. Sense Publishers.

Henderson, M., Selwyn, N., \& Aston, R. (2015). What works and why? Student perceptions of "useful" digital technology in university teaching and learning. Studies in Higher Education, 0(0), (s. 1-13). http://doi.org/10.1080/03075079.2015.1007946

Hiim, H., \& Hippe, E. (1993). Læring gjennom opplevelse, forståelse og handling : en studiebok i didaktikk (6 oplag 1996). Oslo: Universitetsforlaget.

Holgaard, J. E., Ryberg, T., Stegeager, N., Stentoft, D., \& Thomassen, A. O. (2014). PBL: Problembaseret læring og projektarbejde ved de videregående uddannelser. Frederiksberg: Samfundslitteratur.

Hüttel, H \& Gnaur, D. (2015). If PBL is the answer, then what is the problem?

Illeris, K. (2006). Læring (2. reviderede udgave.). Frederiksberg: Roskilde Universitetsforlag.

Jungk, R., \& Müllert, N. (1984). Håndbog i fremtidsværksteder. oversat efter: zukunftwerkstaetten, wege zur wiederbelebung der demokratie, af nielsen, birger steen. 
Kolmos, A. (2002). Forandringer til projektarbejde og PBL - hvad og hvordan? Ii A. Kolmos \& L. Krogh (Eds.), Projektpædagogik i udvikling (s. 33-52). Aalborg: Aalborg Universitetsforlag.

Kolmos, A., Fink, F. K., \& Krogh, L. (2004). The Aalborg model: problembased and project-organized learning. In Kolmos, Anette : Fink, Flemming K.: Krogh, Lone (red.), The Aalborg model : progress, diversity and challenges (s. 9-18). Denmark: Aalborg Universitetsforlag.

Konnerup, U., \& Dirckinck-Holmfeld, L. (2016). Future Workshop as a Pedagogical Framework for Doing Problem Based Learning: An Exemplary learning design for a 6 Weeks Intermediate-Scale, On-Campus University Course. In Designs for Learning, 5th INTERNATIONAL CONFERENCE designing new ecologies. Aalborg Universitetsforlag.

Krogh, L. (2002). Argumenter for projektpædagogik. I A. Kolmos \& L. Krogh (red.), Projektpædagogik i udvikling. Aalborg: Aalborg Universitetsforlag.

Laurillard, D. (2002). Rethinking University Teaching: A Conversational Framework for the Effective Use of Learning Technologies (London: RoutledgeFalmer).

Laurillard, D. (2008). Technology Enhanced Learning as a Tool for Pedagogical Innovation. Journal of Philosophy of Education, 42(3-4), (s.521-533). http://doi.org/10.1111/j.1467-9752.2008.00658.x

Lave, J., \& Wenger, E. (1991). Situated learning: Legitimate peripheral participation. Cambridge Univ Pr.

Negt, O. (1971). Soziologische Phantasie und exemplarisches Lernen: zur Theorie der Arbeiterbildung.[6., völlig überarb. Neuausg. Europäische Verlagsanstalt.

Piaget, J. (2002). The language and thought of the child (3rd ed.). London ;;New York: Routledge.

Savin-Baden, M. (2007). A practical guide to problem-based learning online. London; New York: Routledge.

Sheets-Johnstone, M. (2011). The primacy of movement (Expanded 2nd ed). Amsterdam ; Philadelphia: John Benjamins Pub. Co.

Thomsen, D. L., Sørensen, M. T., \& Ryberg, T. (2016). Where have all the students gone? They are all on Facebook Now. I S. Cranmer, M. de Laat, T. Ryberg, \& J.-A. Sime (Eds.), Proceedings of the 10th International Conference on Networked Learning 2016. Lancaster.

Voogt, J., \& Roblin, N. P. (2012). A comparative analysis of international frameworks for 21 st century competences: Implications for national curriculum policies. Journal of Curriculum Studies, 44(3), 299321. 
Vygotsky, L. (1978). Mind in society : the development of higher psychological processes. Cambridge Mass.: Harvard University Press.

Westbury, I. (1998). Didaktik and Curriculum Studies. I B. Gundem \& S. Hopmann (Eds.), Didaktik and or curriculum : an international dialogue (s. 47-78). New York: P. Lang.

Wenger, E. (2004). Praksisfællesskaber: læring, mening og identitet. Kbh.: Hans Reitzel. 